\title{
LGBTQ Collection Assessment: Library Ownership of Resources Cited by Master's Students
}

\section{Vince Graziano}

\begin{abstract}
Lesbian, Gay, Bisexual, Transgender and Queer (LGBTQ) Studies and the broader discipline of sexuality studies are multidisciplinary fields that require a different approach to collection development in academic libraries. Many library collections budgets reflect the traditional divisions by academic department, and multidisciplinary fields often transcend these conventional boundaries. The concept of one selector for one department, while being a well-established and practical approach to collection building, is limited in breadth and scope and is not necessarily suitable for multidisciplinary fields. This study uses citation analysis to assess the LGBTQ collection at Concordia University Libraries, to ascertain collection strengths and weaknesses, and to recommend collaborative collection development as a viable method of building an excellent collection in a multidisciplinary subject area.
\end{abstract}

\section{Introduction}

LGBTQ Studies is a relatively new and emerging field. In a special issue published in 1993, the Journal of Homosexuality acknowledged that gay and lesbian studies had "emerged" by the early 1990s. ${ }^{1}$ The social movements of both gay liberation and lesbian feminism, after the Stonewall riots of 1969, and the growth of lesbian and gay publishing are among the developments that converged in the 1970s when individual courses in gay and lesbian studies began appearing in colleges and universities in the United States and Canada. ${ }^{2}$ The City College of San Francisco (CCSF) was one of the first institutions of higher learning to create a course in the English department entitled Gay Literature in 1972, and they also established the first Gay and Lesbian Studies Department in the United States in $1988 .^{3}$ In Canada, the University of Toronto School of Continuing Studies was at the forefront: in the mid-1970s, a sociology professor taught a course entitled The Gay Experience: A Sociological Perspective. ${ }^{4}$ In 1998, the university introduced the Sexual Diversity Studies program and, in 2008, the graduate program in Sexual Diversity Studies was launched, the first of its kind in Canada. By 2007, at least 30 colleges and universities in the United States offered multidisciplinary minors in LGBTQ studies. $^{5}$

LGBTQ and sexuality studies are continuing to expand at the undergraduate and graduate levels in several colleges and universities, including Concordia University.

Vince Graziano is a Reference Librarian in Webster Library at Concordia University; e-mail: vince.graziano@concordia.ca. (C) 2016 Vince Graziano, Attribution-NonCommercial (http://creativecommons.org/ licenses/by-nc/3.0/) CC BY-NC. 
Library collections need to grow alongside this expansion. Much like women's studies and African American studies that emerged in the 1970s, sexuality studies present challenges to collection development. Emergent programs may be small compared to large academic departments, but they still merit concerted attention by selectors. Support for interdisciplinary programs belongs to multiple selectors who can ensure collection quality by broadening the scope of collection development beyond a single discipline. Such is the case for LGBTQ and sexuality studies.

Campus climate is an important element in the development and expansion of LGBTQ courses and programs. Concordia is a large urban university located in Montreal, Quebec, Canada. In 1977, the province of Quebec became the first jurisdiction in North America to include sexual orientation as a prohibited ground for discrimination. Montreal is generally considered to be an open and tolerant city. It is within this context that Concordia University "dares to be different" and applauds diversity in its mission statement. The university is a safe and welcoming campus for LGBTQ students and faculty. Sexual orientation is included in the nondiscrimination clause of the collective agreement between the university and the faculty association, which includes librarians. The LGBTQ student collective, Queer Concordia, is an active organization of volunteers that is funded through a $\$ 0.02$ per credit fee levy, which was approved by undergraduate students in a referendum conducted by the Concordia Student Union in April 2011. It is noteworthy that two other initiatives for funding were voted down. ${ }^{6}$ Queer Concordia also offers a small library consisting of about 400 books, mainly nonacademic, as well as some recent issues of the Advocate, a leading LGBTQ popular periodical. Overall, the university is a safe place to study, work, teach, and conduct research on LGBTQ topics. The climate for gender and sexual diversity is more than just tolerant; it is accepting and respectful.

It is within this respectful climate that the study of sexuality at Concordia is expanding, drawing from many disciplines in the humanities, social sciences, and fine arts. The first lesbian studies course was established in 1985 at the Simone de Beauvoir Institute, which houses the Women's Studies Department. ${ }^{7}$ In 1989, the first gay studies course on literature and film was introduced. In 1998, Concordia inaugurated its Minor in Interdisciplinary Studies in Sexuality, which includes several LGBTQ courses. In 2014, the University Senate approved the Major, with final governmental approval pending. The Minor is managed through the Department of Cinema, while the Major will be administered through the Simone de Beauvoir Institute. Both programs are offered jointly by the Faculty of Arts and Science and the Faculty of Fine Arts. Several faculty members have expertise in LGBTQ and sexuality studies in each faculty, enabling them to supervise graduate students. Over the past 30 years, curriculum growth has generated increasing collection development activity to such an extent that several members of the Concordia community (faculty, students, librarians) have come to believe that Concordia Libraries have an excellent collection in LGBTQ and sexuality studies. This hypothesis has not been tested empirically.

Graduate students are important user groups in any university, and they require an adequate collection for their research. Citation analysis that includes the examination of library ownership of cited materials is one method of collection assessment. The bibliographies of local theses and dissertations are readily available resources in academic libraries, and they can be used to evaluate specific sections of a collection. It should be noted that there are no plans to establish a master's degree in LGBTQ or sexuality studies at Concordia University, but there is sufficient graduate student interest and faculty expertise in LGBTQ studies to justify a collection assessment for this level of research. Master's theses have been written on LGBTQ topics in various departments, including Art History, Communication Studies, Creative Arts Thera- 
pies, Education, English, Film Studies, Geography, Political Science, Sociology and Anthropology, and Theological Studies. One thesis was written within the university's Special Individualized Program or SIP, which emphasized multi- or interdisciplinary scholarship (see table 1).

This project examines 3,243 citations in the bibliographies of 28 theses written at Concordia University between 1991 and 2013. One of the major goals of this study is to compile data with which to assess the current collection's capacity to support graduate research, specifically at the master's level, in LGBTQ studies. A second goal is to identify those items that the library does not own and to ascertain collection gaps or weaknesses. There are several ways to examine ownership. One is to count all the citations and determine how many and what percentage of items are in the collection, using other studies as benchmarks. Another more specific way is to examine the citations that are classified in LGBTQ studies, defined by the Library of Congress classification range from HQ74 to HQ77.95, which includes works of homosexuality, bisexuality and transgenderism. It is also useful to examine the ownership of materials classified in the broader field of sexuality studies, defined by the Library of Congress classification ranges HQ12HQ449 and HQ1075-HQ1075.5, excluding LGBTQ citations. An important element of this collection assessment is to determine the ownership for each format to gain an understanding of the types of resources that graduate students use and to see if there are differences in the library holdings for each format.

\section{Literature Review}

Numerous citation analyses have been published since Gross and Gross pioneered the methodology by studying the usage of journals in chemistry. ${ }^{8}$ Many publications since then have examined journal citation patterns, whether they evaluated the journal collection, produced a core list of journals, or examined the ratio between monographs and serials in a given field of study or discipline. Most of these papers focused on faculty research. The 1973 study by Chambers and Healey was one of the early publications in which the citation patterns of master's students were studied in conjunction with collection development or management. The authors recorded 2,198 journal citations in 168 master's theses in the fields of education and English in an effort to identify the most cited journals. They found that the library held 90 percent of the journal citations in English theses and 93 percent in education. ${ }^{9}$

Some studies examined master's theses but did not include library ownership. For example, in 1987, Judy Reynolds investigated the citation patterns in 646 master's theses in several departments to determine the types of materials used by students. ${ }^{10}$ In 1990 , Perritz and Sor surveyed the citations in master's theses in psychology in four Israeli universities during the years 1983-1987. They generalized their findings to the field of psychology as a whole, concluding that the field has "strong ties" to other areas of 
study, namely medicine, social sciences, sciences, and humanities. ${ }^{11}$ In 1994 , Rosalind Walcott studied the theses and dissertations in the biological sciences in the most recent four years to help with a serials review that necessitated cutting up to 30 percent of subscriptions. She chose graduate students, rather than faculty, because they were the "most active users of the serial collection." ${ }^{12}$ These early studies established the use of master's theses as legitimate sources for citation analysis.

In an investigation of 34 studies that employed citation analysis, Hoffman and Doucette analyzed the descriptions of methodologies, stating that among the common approaches were to examine citation patterns of specific user groups in a particular department and to assess whether the local collection met users' needs. ${ }^{13}$ In addition to the article by Chambers and Healey, several studies have applied both of these elements. Using philosophy dissertations, Jean-Pierre Herubel found that the library held a "strong showing" of 83 percent of the titles cited. ${ }^{14}$ In her examination of journal use in psychology master's theses, Joy Thomas discovered that 66 percent of the journal titles were owned and that 92 percent of the journal citations were held locally. ${ }^{15}$ Sylvia and Lesher assessed the local journal collection by also examining master's theses in psychology. They found that the library held 77 percent of the most heavily cited 75 titles. ${ }^{16}$ Margaret Sylvia evaluated the use of the journal collection by using the bibliographies of research papers written by graduate and undergraduate psychology students. She found that the library held or licensed 87 percent of the citations to journal articles. ${ }^{17}$ In another article by Thomas, this one examining master's theses in social work, the percentage of locally owned journals was 91.6 percent. ${ }^{18}$ Erin Smith assessed the usefulness of the library collection by looking at the citation patterns in 13 master's theses and $17 \mathrm{PhD}$ dissertations in the arts and humanities, education, sciences, and social sciences. She found that the Libraries owned or licensed 87 percent of works cited. ${ }^{19}$

Journals were the main focus of most studies of library ownership. In his analysis of master's theses in history, Graham Sheriff was one of the few who examined the holdings for specific document types. He noted that the library held 41 percent of total citations, 46.8 percent of monographs, 72.6 percent of journal articles, 49.5 percent of popular periodicals, and 50 percent of chapters in edited books. ${ }^{20}$ Though not looking at theses and dissertations, Kellsey and Knievel examined the citations in 28 monographs published by humanities faculty between 2004 and 2009. They found that the library owned 76 percent of the cited resources, with variations by discipline; the percentages were 67 percent for classics, 72 percent for history, 81 percent for philosophy, and 84 percent for English. ${ }^{21}$ Edwards and Jones sampled 3,372 citations from 107 doctoral dissertations in three disciplines. They found that the library owned or licensed 97 percent of journal articles cited in education, 99 percent in psychology, and 97 percent in social welfare-all very high ratios. They also calculated the percentages of books held, which were 86 percent in education, 87 percent in psychology, and 72 percent in social welfare. ${ }^{22}$ The average of all the above percentages is 78 percent and the median is 84 percent, which is a reasonable measurement to set as a benchmark for this study.

There has been one citation analysis of LGBTQ studies, but none that applied bibliographic analysis through the lens of master's theses and none that assessed the LGBTQ collection. In reviewing the scholarly literature in LGBTQ studies, Karen Antell selected 131 articles published between 1974 and 2010 from the LGBT Life database, with a sample size of 4,321 total citations. One of the questions she wanted to answer was whether the scholarly literature was based on mainstream academic literature or popular publications, such as community or activist periodicals. She found that only 4.3 percent of citations were to popular periodicals and that a total of 6 percent of references were to popular books and serials. In addition, she assigned five broad discipline categories - social sciences, humanities, science/technology, medicine, and 
law - to the citations for scholarly journals, academic and popular books, and conference papers. She did not allocate a discipline to popular periodicals because they are "generally multidisciplinary" such as newspapers and magazines. ${ }^{23}$ It is unclear if there was any use of LGBTQ magazines such as community and activist periodicals in the scholarly literature of LGBTQ studies.

Very little has been published on LGBTQ collections in academic libraries. Some studies dealt with user perceptions of the library's LGBTQ collection. Melissa Adler surveyed faculty, graduate and undergraduate students, academic staff and librarians. Of the 88 percent of users who consulted the library to research LGBTQ topics for academic work, 54 percent of them were "moderately to very satisfied" with their library's LGBTQ collection, leading Adler to conclude that librarians who build strong LGBTQ collections can have a "tremendous impact" on the experience of library users. ${ }^{24}$ In a survey of Canadian academic library users, Pascal Lupien reports a very similar ratio; 53 percent of non-LGBTQ respondents believed that there was "good coverage" of print LGBTQ materials, but only 14 percent of self-identified LGBTQ participants thought that the print collection was good, with the most common complaint being that books were outdated..$^{25}$

It is not clear what types of print materials LGBTQ users needed or wanted from an academic library. Suzy Taraba, back in 1990, stated that an academic library has the responsibility to support all students' information needs, including supplementary materials such as coming-out stories; and she concluded that, with the "rise of scholarly study of popular culture, materials once considered strictly extracurricular often serve a dual purpose." ${ }^{26}$ K.L. Clarke advises that resources "must be acquired that speak to non-academic and personal interests, such as coming out, health, intimate relationships, parenting, religion, and safer sex practices. ${ }^{27}$ It may be such topics that Canadian self-identified LGBTQ library users were hoping to find in academic libraries.

There is an interesting discussion regarding responsibility for LGBTQ collection development. Adler asks if "libraries need LGBTIQ [Lesbian, Gay, Bisexual, Transgender, Intersex, and Queer/Questioning] subject specialists, and should they select materials for every discipline that might touch upon this area?" In her survey of 33 academic librarians, she reported that $13(39 \%)$ of them stated that there was a librarian in their library who was responsible for LGBTQ collections. She acknowledged that shared responsibility is a possibility by emphasizing one librarian's comment that "any selector" can acquire LGBTQ material that "obviously" belongs to many disciplines. ${ }^{28}$ Clarke also asked some questions regarding responsibility, namely: "Is it solely the responsibility of the LGBTIQ selector to make purchasing decisions?" Stating that LGBTQ librarians primarily select items in the Library of Congress classification range HQ71-HQ77.95, she writes that "collaborative collection development can work if all librarians involved possess the broad understanding that everyone can have a hand in selecting and purchasing relevant materials." ${ }^{29}$

In an article that discussed the challenges that librarians face regarding the interdisciplinarity of women's studies, Susan Searing recognized that traditional library book budgets are frequently divided by academic department and defined by Library of Congress classification. She stated that this is a "serious challenge" to interdisciplinary programs such as women's studies; and she acknowledged a "new emphasis on cooperative collection building," which can be seen as a way to cope with interdisciplinarity. ${ }^{30}$ Taraba also recognized a shared approach by stating that "gay and lesbian materials may be collected by librarians with responsibility for collecting in different subject areas." ${ }^{31}$ In light of these four publications, shared responsibility for collection development becomes an important consideration for academic libraries that need to build or strengthen multidisciplinary collections, but no study demonstrates whether it works. 
The studies by Adler and Lupien about user satisfaction with LGBTQ collections are important steps in understanding the information needs of LGBTQ library users in an academic setting. Taraba, Adler, and Clarke guided academic librarians in developing LGBTQ collections. One of the goals of Adler's study was to serve as a starting point to help librarians to develop LGBTQ collections. Her study, however, is limited to Wisconsin public and private academic libraries, and she surveyed only 26 students and 33 librarians, which are small sample sizes. Clarke's essay discusses several aspects of building an academic collection. Although she states that university climates have improved for LGBTQ students over time and that campuses have become more inclusive, she asserts that LGBTQ selectors concentrate on the Library of Congress classification range HQ71-HQ77.95. This is insulting to LGBTQ people, because bestiality and other such sexual deviations are classified in HQ71-these sexual practices are not and should not be associated with LGBTQ people.

In an essay that outlined the challenges involved in creating or strengthening LGBTQ collections, Taraba identified the Library of Congress classification range for gay and lesbian materials to be HQ74-HQ76, ignoring transgenderism, which has garnered considerable attention since the publication of her essay in 1990. Other statements are equally outdated. She wrote that gay and lesbian collections have a "hidden clientele" who suffer from discrimination and lack of acceptance. This may have been true back in 1990; though more work in this direction is still needed, major social changes since then have led to greater visibility of LGBTQ people on college and university campuses. Notwithstanding their limitations, the essays by Taraba, Adler, and Clarke started the conversation about LGBTQ collections in academic libraries. However, they discussed how to do collection development but did not show LGBTQ collection development in practice. This study uses citation analysis to assess the LGBTQ collection, to ascertain collection strengths and weaknesses, and ultimately to discuss how the collection was built. In so doing, it adds to the literature by providing a case study of LGBTQ collection development in an academic library.

\section{Methodology}

The first step was to select an appropriate number of theses with enough citations to form a decent sample size. Since Concordia Libraries abandoned the use of subject headings for the cataloguing of theses and dissertations, several keywords were used to search both the library catalog and the institutional repository. It is mandatory to deposit theses and dissertations in the institutional repository named Spectrum, which is searchable by keyword. The keywords used to search both resources, which include abstracts for most theses, were: gay, gays, lesbian*, homosex ${ }^{*}$, queer ${ }^{*}$, bisexual ${ }^{*}$, transgender*, transsexual ${ }^{*}$, intersex*, and lgbt*. Only those theses that represented LGBTQ topics prominently in their titles and abstracts were chosen. Theses about HIV/AIDS were selected only if they featured LGBTQ communities. Theses written in French were removed from the list because they were considered to have a whole different set of citations, and they may not be comparable with their English language counterparts. Doctoral dissertations were eliminated as they were few in number and were outside the scope of this paper. Literary works submitted in partial fulfilment of the requirements for a master's degree in English (Creative Writing) were also excluded, as they do not have bibliographies. It was decided to use all of the remaining 28 theses that matched these criteria.

An identification number was given to each thesis, and the following information was recorded: number of citations, number of pages, year of submission, and the name of the department. The number of citations ranged from a low of 28 to a high of 529, with an average of 119 and a median of 84 . The number of pages also varied, spanning from 45 to 329 . Using Excel spreadsheets, the following data was compiled for each 
of the 3,243 citations: author, document title, format, publication year, age, language, and library holdings. Ownership was defined as physical holdings as well as access to licensed material. Age was calculated as the date of submission of the thesis less the date of publication of a citation; an Excel formula was applied to this field. Document title refers to book titles for monographs and edited collections and to serial titles for journal articles and popular periodicals and newspapers.

If some of the information was unknown, unverifiable, or not applicable, the field was left blank. For example, the publication year and age for undated websites were left blank, as were the columns for Library of Congress classification, discipline, and holdings. A newspaper article accessed through a newspaper website received a newspaper article designation and not a website, but the holdings column was left blank. A Library of Congress call number was accorded to each citation to monographs, journals, edited books, and popular periodicals and newspapers. A newspaper article referred to general newspapers, while a popular periodical was defined as a general interest magazine or a community periodical. Each citation was verified in the library catalog to obtain a call number. If the item was not found, then WorldCat was used for monographs and Ulrich's for serials. Based on the classification, a discipline or area of study was assigned to each applicable citation. For the purposes of this paper, only two areas of study are relevant: LGBTQ studies and sexuality studies.

\section{Results}

The library owned 2,375 of the 3,243 citations, or 73 percent. This is below average compared to the percentages in previous studies and would normally indicate that the collection is good but somewhat ordinary and unexceptional. A different picture emerges when looking at the percentages of held items by format. Table 2 lists the top formats, as defined by the number of citations, along with the percentages of total citations and the numbers and percentages held, which were 86 percent for monographs, 85 percent for journal articles, and 90 percent for chapters in books. The percentages for these three formats show a stronger collection than the 73 percent would otherwise indicate. It is clear that the percentage of ownership of newspaper articles is below average at 70 percent and that the collection of popular periodicals is poor, with only 54 percent. At 11.87 percent of total citations, popular periodicals represent a smaller but seemingly significant portion of items cited in LGBTQ master's theses. When popular newspapers are added, the percentage becomes 15.88 percent.

\begin{tabular}{|l|c|c|c|c|}
\hline \multicolumn{5}{|c|}{ TABLE 2 } \\
Citations and Ownership by Format \\
\hline $\begin{array}{c}\text { Number of } \\
\text { Citations }\end{array}$ & $\begin{array}{c}\text { \% of Total } \\
\text { Citations }\end{array}$ & $\begin{array}{c}\text { Number of } \\
\text { Citations Held }\end{array}$ & $\begin{array}{c}\text { \% of Citations } \\
\text { Held }\end{array}$ \\
\hline Monographs & 1,201 & $37.03 \%$ & 1,031 & $86 \%$ \\
\hline Journal Articles & 709 & $21.86 \%$ & 602 & $85 \%$ \\
\hline Chapters in Books & 463 & $14.28 \%$ & 419 & $90 \%$ \\
\hline Popular Periodicals & 384 & $11.87 \%$ & 205 & $54 \%$ \\
\hline Newspaper Articles & 130 & $4.00 \%$ & 91 & $70 \%$ \\
\hline Websites & 122 & $3.76 \%$ & $\mathrm{n} / \mathrm{a}$ & $\mathrm{n} / \mathrm{a}$ \\
\hline Conference Addresses & 88 & $2.71 \%$ & 0 & $0 \%$ \\
\hline Other & 146 & $4.50 \%$ & 27 & $18 \%$ \\
\hline Total & 3,243 & $100.01 \%$ & 2,375 & $73 \%$ \\
\hline
\end{tabular}


Holding only 58 percent of popular periodicals and newspapers seems insufficient to support master's level research.

Overall, 453 of the 633 LGBTQ citations were owned by the library for a percentage of 72 percent, which is well below average. Table 3 lists the number of LGBTQ citations for each format, the number that are owned, as well as the percentages of LGBTQ citations owned. The breakdown by format presented a much different scenario: 90 percent of citations to monographs were owned, 100 percent for references to journal articles, and 96 percent for chapters. These are all very high percentages and add empirical evidence to support the hypothesis that Concordia Libraries hold an excellent collection in LGBTQ studies. Once again, however, popular periodicals did not fare as well. Only 26 percent of LGBTQ magazines were held. This is a dismal result.

\begin{tabular}{|l|l|c|c|c|c|c|}
\hline \multicolumn{7}{|c|}{ TABLE 3 } \\
\hline $\begin{array}{l}\text { LC Call } \\
\text { Numbers }\end{array}$ & Format & $\begin{array}{c}\text { \# of } \\
\text { Total } \\
\text { Citations }\end{array}$ & $\begin{array}{c}\text { \# of } \\
\text { LGBTQ } \\
\text { Citations }\end{array}$ & $\begin{array}{c}\% \text { of } \\
\text { Total } \\
\text { LGBTQ } \\
\text { Citations }\end{array}$ & $\begin{array}{c}\text { \# of } \\
\text { LGBTQ } \\
\text { Citations } \\
\text { Owned }\end{array}$ & $\begin{array}{c}\text { \% of } \\
\text { LGBTQ } \\
\text { Citations } \\
\text { Owned }\end{array}$ \\
\hline $\begin{array}{l}\text { HQ 74- } \\
\text { HQ 77.95 }\end{array}$ & Monographs & 1,201 & 261 & $22 \%$ & 236 & $90 \%$ \\
\cline { 2 - 8 } & Journal Articles & 709 & 68 & $10 \%$ & 68 & $100 \%$ \\
\cline { 2 - 8 } & Chapters & 463 & 99 & $21 \%$ & 96 & $96 \%$ \\
\cline { 2 - 8 } & Periodicals & 384 & 205 & $53 \%$ & 54 & $26 \%$ \\
\cline { 2 - 8 } & Total & 2,758 & 633 & $23 \%$ & 453 & $72 \%$ \\
\hline
\end{tabular}

The same breakdown by format was applied to the citations classified in sexuality studies. Table 4 shows that the library owned 87 percent of references to monographs, 96 percent of those to journal articles, and 83 percent to chapters. The total percentage was 88 percent. There were no magazines or newspapers classified in sexuality studies. Though not as high as the ratios for LGBTQ studies, the percentages of citations held for sexuality studies are quite respectable, particularly for journal articles. With LGBTQ and sexuality citations combined (see table 5), the percentages were 89 percent for monographs, 98 percent for journal articles, and 91 percent for chapters. With these percentages, it is reasonable to state that Concordia Libraries have developed an excellent collection in LGBTQ and sexuality studies, at least for books and journals.

\begin{tabular}{|c|c|c|c|c|c|c|}
\hline \multicolumn{7}{|c|}{$\begin{array}{c}\text { TABLE } 4 \\
\text { Sexuality Citations by Format and Ownership }\end{array}$} \\
\hline $\begin{array}{l}\text { LC Call } \\
\text { Numbers }\end{array}$ & Format & $\begin{array}{c}\text { \# of } \\
\text { Citations }\end{array}$ & $\begin{array}{c}\text { \# of } \\
\text { Sexuality } \\
\text { Citations }\end{array}$ & $\begin{array}{c}\% \text { of } \\
\text { Total } \\
\text { Sexuality } \\
\text { Citations }\end{array}$ & $\begin{array}{c}\# \text { of } \\
\text { Sexuality } \\
\text { Citations } \\
\text { Owned }\end{array}$ & $\begin{array}{c}\% \text { of } \\
\text { Sexuality } \\
\text { Citations } \\
\text { Owned }\end{array}$ \\
\hline \multirow{4}{*}{$\begin{array}{l}\text { HQ 12-HQ } \\
449 \& \\
\text { HQ 1075- } \\
\text { HQ 1075.5 } \\
\text { Excluding } \\
\text { HQ 74-77.95 }\end{array}$} & Monographs & 1,201 & 136 & $11 \%$ & 118 & $87 \%$ \\
\hline & $\begin{array}{l}\text { Journal } \\
\text { Articles }\end{array}$ & 709 & 50 & $7 \%$ & 48 & $96 \%$ \\
\hline & Chapters & 463 & 58 & $13 \%$ & 48 & $83 \%$ \\
\hline & Total & 2,373 & 244 & $15 \%$ & 214 & $88 \%$ \\
\hline
\end{tabular}


TABLE 5

Sexuality and LGBTQ Citations by Format and Ownership

\begin{tabular}{|c|c|c|c|c|c|c|}
\hline $\begin{array}{l}\text { LC Call } \\
\text { Numbers }\end{array}$ & Format & $\begin{array}{l}\text { \# of Total } \\
\text { Citations }\end{array}$ & $\begin{array}{c}\text { \# of } \\
\text { Sexuality } \\
\& \\
\text { LGBTQ } \\
\text { Citations }\end{array}$ & $\begin{array}{c}\% \text { of } \\
\text { Sexuality } \\
\& \\
\text { LGBTQ } \\
\text { Total } \\
\text { Citations } \\
\end{array}$ & $\begin{array}{c}\# \text { of } \\
\text { Sexuality } \\
\& \\
\text { LGBTQ } \\
\text { Citations } \\
\text { Owned }\end{array}$ & $\begin{array}{c}\% \text { of } \\
\text { Sexuality } \\
\& \\
\text { LGBTQ } \\
\text { Citations } \\
\text { Owned }\end{array}$ \\
\hline \multirow{5}{*}{$\begin{array}{l}\text { HQ 12-HQ } \\
449 \& \\
\text { HQ 1075- } \\
\text { HQ 1075.5, } \\
\text { inclusive }\end{array}$} & Monographs & 1,201 & 397 & $33 \%$ & 354 & $89 \%$ \\
\hline & $\begin{array}{l}\text { Journal } \\
\text { Articles }\end{array}$ & 709 & 118 & $17 \%$ & 116 & $98 \%$ \\
\hline & Chapters & 463 & 157 & $34 \%$ & 144 & $91 \%$ \\
\hline & Periodicals & 384 & 205 & $53 \%$ & 54 & $26 \%$ \\
\hline & TOTALS & 2,757 & 8773 & $32 \%$ & 667 & $76 \%$ \\
\hline
\end{tabular}

Most selectors would naturally wonder what cited items are not in the LGBTQ collection. In the category of chapters in edited books, there were only three books that were not held by the library, each cited once. The books were published in 1990, 1994, and 1999. Two of the books are available locally at a nearby university library, and the third book is not available. The age of the books, and the fact that they were cited only once, eliminates them from retrospective collection development. There were 24 LGBTQ monographs that were not owned by the library. The oldest monograph was published in 1977 and the most recent in 2001. Only one book was cited in two theses; all the others were cited once. Since 77 percent of the total cited items with publication dates were thirteen years or less and since there were low numbers of citations, all 24 books were excluded from retrospective collection development consideration.

\section{Discussion}

The only glaring collection weakness was LGBTQ popular periodicals. A closer examination of the data, however, revealed a diminishing trend in usage. For the 20 theses written from 1999 onward, there were only 16 citations to LGBTQ popular periodicals, representing 0.95 percent of total citations for these theses. The percentage of total citations that are popular periodicals for these 20 theses is 2.61 percent. Of the 28 theses in this study, one in particular used 202 citations to popular magazines, 145 of which were citations to LGBTQ periodicals. If the 202 were removed from the total number of citations to popular periodicals and subtracted from the total number of citations, the percentage for this document type would plummet from 11.87 percent to 5.98 percent, thereby reducing the relative importance of popular periodicals. This figure is much closer to the 4.3 percent reported by Antell. This lower percentage and the diminishing number of citations to popular magazines over time provide further evidence that LGBTQ studies is based on scholarly literature rather than community or activist periodicals, as Antell has shown.

Even with the 202 citations removed, the percentage of LGBTQ popular periodicals owned would still be a lowly 23 percent. Among the LGBTQ popular magazines that the library did not hold are the Advocate, with 21 citations from 1984 to 1996; Gay Community News, with 35 citations from 1985 to 1991; Out, with nine citations mainly from the 1990s; and Xtra, a Toronto LGBTQ community periodical, with 59 citations from 1988 to 1997. Full-text access to all four of these periodicals is available on the LGBT Life with Full Text database, but the starting dates for the full text are later than these 
dates. It may be possible that future use of LGBTQ periodicals will be served by LGBT Life with Full Text, a database to which Concordia does not subscribe. The acquisition of this database, while not gaining access to the earlier issues of some LGBTQ popular periodicals, would nevertheless redress some of the gaps in the LGBTQ collection by providing full-text electronic access to more recent LGBTQ popular periodicals, as well as some older ones, such as the entire run of the Body Politic, an important Canadian LGBTQ periodical that was published from 1971 to 1987. The Body Politic was cited 25 times.

Some issues of journals and magazines, such as the Advocate, the Body Politic, the Journal of Lesbian Studies and the Journal of Homosexuality, were purchased in print or microform with departmental funds, but most of the LGBTQ and sexuality journals and magazines were obtained through licensing agreements and paid on access funds, including Project MUSE, Taylor \& Francis, and Academic Search Complete. In these days of access rather than physical ownership of periodicals, libraries usually purchase packages of journals and magazines through publishers or aggregators, often through consortia. The LGBTQ program, as well as sexuality studies, has benefited greatly from this development, as the library has electronic access to the full runs of the Journal of Homosexuality, GLQ, Archives of Sexual Behavior, the Journal of Sex Research, and many others.

Holding 100 percent of journals classified in LGBTQ studies seems excessive. No other study reported such a percentage. It would appear that there exists a "convenience bias" toward journals owned by the library, as reported by Sylvia, who expected that "materials the library owns will be more often used than those it does not own." 32 One of the characteristics of convenience bias, according to Ellen Sexton, is increasing journal usage over time. ${ }^{33}$ There is no discernible pattern of greater journal usage over time in the theses in this study. There were only seven LGBTQ journals cited. They are the Journal of Homosexuality, GLQ: A Journal of Lesbian and Gay Studies, the Journal of Gay, Lesbian and Bisexual Identity, the Journal of GLBT Family Studies, the Journal of Lesbian Studies, the Journal of LGBT Youth, and the Journal of Gay and Lesbian Social Services. In addition, Ulrich's lists thirteen active LGBTQ scholarly journals published in the United States, Canada, and Australia. Two are open access and only one is not owned by Concordia. It is Lesbian Gay Law Notes, a specialized journal that is available full text on the LGBT Life with Full Text database. The convenience bias is not at all apparent in the use of LGBTQ popular periodicals, with students obviously willing and able to bypass the library and the campus for access to these resources. Contrary to a convenience bias, holding 100 percent of LGBTQ journals cited, as well as holding ten of the eleven subscription-based journals listed in Ulrich's, is indicative of an excellent collection.

It is difficult, if not impossible, to surmise where graduate students accessed LGBTQ popular periodicals, particularly those issues published in the 1980s and 1990s. Queer Concordia's little library includes only recent issues of the Advocate, to which the library subscribes in print and online from 1996. It is possible that students relied on their own personal libraries or those of faculty members or friends. Another possibility is the Quebec Gay Archives, which is located in Montreal. They have selected issues of the Advocate and Xtra, with many gaps, but they don't hold Gay Community News or Out. Access to the archives is usually by appointment; and it is also open for two hours per week, which is not necessarily convenient. Another option is interlibrary loans.

One of the elements missing in the discussion of convenience bias is graduate students' use of interlibrary loans (ILL). Sylvia does not mention it. Sexton states that students cite journal articles available electronically "in preference" to those available through interlibrary loan (as well as in print and at other libraries), but she does not provide evidence of interlibrary loan usage. ${ }^{34}$ In a 2003 study of ILL at the University 
of Mississippi Libraries, Gail Herrera supplies data by user status; the majority of ILL users were graduate students, who represented 46.6 percent of all users, with faculty at 22.8 percent, staff at 9.8 percent, and undergraduate students at 20.9 percent. ${ }^{35}$ The data are remarkably similar at Concordia Libraries, though the measurement is different. In 2010, the latest year available, there were a total of 13,503 ILL requests that specified user status. A majority of 52 percent of all requests were from graduate students, with 21 percent from faculty, 4 percent from staff, and 22.5 percent from undergraduate students. Graduate students' use of ILL would need to be low or negligible to convincingly show the existence of convenience bias, wherein students cite what they can readily access. However, ILL usage by graduate students appears to be quite high, suggesting that they are willing to use ILL to get what they need, which questions the evidence supporting convenience bias. This lends further weight to the argument that citation analyses of graduate students' theses reflect the appropriateness of a library collection.

There is no LGBTQ department at Concordia University. Consequently, there is no departmental fund to purchase monographs and serials for the LGBTQ program. Over the past 17 years, since the creation of the Minor in Interdisciplinary Studies in Sexuality, funding for LGBTQ monographs and videos was obtained through development funds, based on the library portion of the annual donations given to the university, which varied from year to year. Two librarians share collection development responsibility for these funds, which purchases resources that are mainly in the HQ classification range, confirming Clarke's contention. These funds have also been used to purchase recommendations made by faculty and graduate students, many of whom are members of the Coordinating Committee for Interdisciplinary Studies in Sexuality, which consists of a network of 24 faculty, several graduate students, and one librarian. This denotes a strong working relationship between the library and these important user groups, which Adler stated was key to developing LGBTQ collections that meet the needs of users. ${ }^{36}$ In years without funding, or when development funds were spent, titles of interest to LGBTQ studies were sent to subject librarians with a request to purchase, a practice recommended by Clarke. ${ }^{37}$ Librarian requests are normally accepted by other librarians at Concordia. This indicates that there is a cooperative relationship among selectors.

Prior to the creation of the Minor in 1998, there were no special funds to purchase LGBTQ resources. Since 1998, some special funding obtained through donations was available, but these funds were inadequate and needed to be shared with sexuality studies and HIV/AIDS. In some years there was no funding at all. The excellent collection of LGBTQ material was built on the many and varied departmental funds, which are managed by several librarians. Collecting LGBTQ items requires a collaborative collection development strategy, at least a tacit one. At Concordia, there are LGBTQ and sexuality courses offered by several departments, requiring subject librarians to purchase materials in support of such courses. Stating that library work, including collection development, is "collegial in nature," Clarke recognizes a tacit strategy by writing that, in some academic libraries, "there is an understanding among several librarians to consciously buy materials in LGBTIQ Studies." ${ }^{88}$ This is the case at Concordia.

There were more than 40 disciplines or areas of study represented in this citation analysis, reflecting a very wide dispersal of subjects. LGBTQ studies, with its narrow definition by Library of Congress call number, accounted for only 20 percent of total citations. Still, this was the discipline with the highest percentage of citations. The next two disciplines were literature and sexuality studies, each with about 8 percent of total references. This underscores the highly interdisciplinary nature of LGBTQ studies, which has significant implications for collection development. There are many monographs on LGBTQ topics that are classified in other disciplines, as per the Library 
of Congress classification system. For example, books about LGBTQ communities in schools are normally classified in education and books about homosexuality and art are classified in art. Much like women's studies and other interdisciplinary fields, selection for LGBTQ studies involves a collaborative effort, particularly for items that are not classified in LGBTQ studies. It would be an interesting project for future studies to investigate how many items about LGBTQ topics are classified outside the call number range of HQ74 to HQ77.95. For journals, it would be interesting to study the number of articles on LGBTQ topics that are published in mainstream journals.

\section{Next Steps}

There is an abundance of information compiled in this citation analysis. The data will be used to identify the top journals, the ratio of books to journals, the leading authors, the most-cited books, the age and format of materials cited, and the disciplines from which LGBTQ studies borrow. It is important to examine the interdisciplinary nature of LGBTQ studies, along with its broader field, sexuality studies. Learning about Concordia's students and their citing habits in LGBTQ studies may lead to a greater understanding of their research skills and the level of information literacy that they possess, which can inform the design of potential library instruction. Since a citation analysis of the scholarly literature in LGBTQ studies exists, it will be interesting to compare faculty use of information to that of master's students and to determine similarities and differences, thereby increasing knowledge about the field of LGBTQ studies.

\section{Conclusion}

The hypothesis that Concordia Libraries have an excellent collection in LGBTQ studies was tested empirically through a citation analysis of 28 master's theses comprising 3,243 citations. Basic percentage counts of library ownership were not conclusive in the sense that they only presented a partial glimpse into the health of the LGBTQ collection; the 72 percent of the total LGBTQ materials that were owned by the library was well below the average compared to previous studies. A breakdown by document type revealed an above-average collection of books and journals, while also showing a weakness in the holdings of LGBTQ popular periodicals. The declining importance of popular periodicals, representing 0.95 percent of total citations for the twenty theses written from 1999 to 2013, mitigates the impact of the 26 percent ownership of LGBTQ popular periodicals. The high percentages of ownership of books and journals support the hypothesis that Concordia Libraries have an excellent collection, which is appropriate for master's level research in LGBTQ studies.

The bibliographies of master's theses were used to evaluate a particular section of a collection, specifically LGBTQ and sexuality studies. Although the literature on student papers discusses convenience bias, which favors using accessible materials, it does not address the links between graduate student use of interlibrary loan services and the practicality of using readily available material. Data from limited sources shows high usage of ILL by graduate students, but further research into the interconnections between ILL and convenience bias seems warranted. Sylvia's article, in which she discusses convenience bias, is about both graduate and undergraduate student papers. Convenience bias may apply to term papers by undergraduate students and perhaps to course papers by graduate students, both of which have short deadlines, but graduate students have more time to devote to major projects like theses, which require them to be thorough. This paper cites eleven studies of student theses, eight of which deal with library ownership, defined as physical holdings as well as licensed material, thereby validating the use of student theses as legitimate sources for collection assessment.

Two LGBTQ information needs were identified in the literature on LGBTQ collec- 
tion development in academic libraries: the need for curricular and research materials, inherent in an academic setting, and the need for personal and recreational reading, which both Taraba and Clarke emphasized. This paper adds a third LGBTQ information need: the need for LGBTQ popular periodicals, which may serve a dual purpose, as Taraba noted. LGBTQ popular periodicals provide personal and recreational reading, as well as offering contemporary research value on almost any topic of concern to the LGBTQ communities they serve. Academic librarians looking to build or strengthen LGBTQ collections should heed all three of these information needs. This study's poor results in the holdings of LGBTQ popular periodicals need to be addressed. In terms of personal and recreational materials, it is not always possible for academic librarians to purchase nonacademic resources with limited funds. A subscription to LGBT Life with Full Text may provide a partial solution, as well as attending to all three LGBTQ information needs. The database contains more than 160 full-text books, many of which include the personal topics that Clarke and Taraba pointed out. In addition to providing access to academic resources, the database would increase access to some LGBTQ popular periodicals, including the ones identified in this study. The full-text books and popular periodicals found in LGBT Life with Full Text provide added value and a further argument to support such a subscription in academic libraries with programs or courses in LGBTQ studies.

This citation analysis has provided important information about building collections in LGBTQ studies, which can apply to other interdisciplinary fields. There were more than 40 fields of study represented in this paper. Overall, the library held or had access to 86 percent of monographs, 85 percent of journal articles, and 90 percent of chapters in books. This indicates a good collection across all disciplines. The excellent collection was largely built by several selectors who are responsible for departments in two faculties, showing that shared or cooperative collection development works. This can serve as a model for academic libraries that are building LGBTQ collections or other interdisciplinary collections. For academic libraries that need to support individual LGBTQ courses in traditional departments, or LGBTQ content in regular courses, collaborative collection development emerges as a viable model-perhaps a preferred one.

\section{Notes}

1. Henry L. Minton, "The Emergence of Gay and Lesbian Studies," Journal of Homosexuality 24, no. 1/2 (1993): 1.

2. Minton, "The Emergence of Gay and Lesbian Studies," 2-3; Jeffrey Escoffier, "Generations and Paradigms: Mainstreams in Lesbian and Gay Studies," Journal of Homosexuality 24, no. 1/2 (1993): 8.

3. Jack Collins, "Matters of Fact: Establishing a Gay and Lesbian Studies Department," Journal of Homosexuality 24, no. 1/2 (1993): 109-11.

4. "Gay Studies at University of Toronto," Body Politic no. 20 (Oct. 1975): 9.

5. "Gay Studies Thriving on U.S. Campuses," New York Blade 11, no. 36 (Sept. 7, 2007): 7; K.L. Clarke, "LGBTIQ Users and Collections in Academic Libraries," in Serving LGBTIQ Library and Archives Users: Essays on Outreach, Service, Collections and Access, ed. Ellen Greenblatt (Jefferson, N.C.: McFarland, 2011): 84.

6. Simon Liem, "The Referendums," The Link (Apr. 5, 2011), available online at http://thelinknewspaper.ca/article/1437 [accessed 19 January 2015].

7. For a discussion of lesbian studies at Concordia and other Canadian universities, see Carolyn Gammon, "Lesbian Studies Emerging in Canada," Journal of Homosexuality 24, no. 1/2 (1993): 137-60.

8. P.L.K. Gross and E.M. Gross, "College Libraries and Chemical Education," Science 66, no. 1713 (Oct. 28, 1927): 385-89.

9. George R. Chambers and James S. Healey, "Journal Citations in Master's Theses: One Measurement of a Journal Collection," Journal of the American Society for Information Science 24, 
no. 5 (Sept./Oct. 1973): 398.

10. Judy Reynolds, "Master's Candidates' Research Skills," Research Strategies 5, no. 2 (Spring 1987): 80.

11. Bluma C. Peritz and Dina Sor, "The Use of Libraries by Graduate Students in Psychology as Indicated by Citations," Collection Management 12, no. 3/4 (1990): 23.

12. Rosalind Walcott, "Local Citation Studies-A Shortcut to Local Knowledge," Science \& Technology Libraries 14, no. 3 (1994): 1-2.

13. Kristen Hoffman and Lise Doucette, "A Review of Citation Analysis Methodologies for Collection Management," College \& Research Libraries 73, no. 4 (July 2012): 321.

14. Jean-Pierre V.M. Herubel, "Philosophy Dissertation Bibliographies and Citations in Serials Evaluation," Serials Librarian 20, no. 2/3 (1991): 71.

15. Joy Thomas, "Graduate Student Use of Journals: A Bibliometric Study of Psychology Theses," Behavioral \& Social Sciences Librarian 12, no. 1 (1993): 6.

16. Margaret Sylvia and Marcella Lesher, "What Journals Do Psychology Graduate Students Need? A Citation Analysis of Thesis References," College \& Research Libraries 56, no. 4 (July 1995): 316.

17. Margaret J. Sylvia, "Citation Analysis as an Unobtrusive Method for Journal Collection Evaluation Using Psychology Student Research Bibliographies," Collection Building 17, no. 1 (1998): 24.

18. Joy Thomas, "Never Enough: Graduate Student Use of Journals-Citation Analysis of Social Work Theses," Behavioral \& Social Sciences Librarian 91, no. 1 (2000): 10.

19. Erin T. Smith, "Assessing Collection Usefulness: An Investigation of Library Ownership of the Resources Graduate Students Cite," College \& Research Libraries 65, no. 5 (Sept. 2003): 351.

20. Graham Sheriff, "Information Use in History Research: A Citation Analysis of Master's Level Theses," portal: Libraries and the Academy 10, no. 2 (Apr. 2010): 175.

21. Charlene Kellsey and Jennifer Knieval, "Overlap between Humanities Faculty Citation and Library Monograph Collections, 2004-2009," College E Research Libraries 73, no. 6 (Nov. 2012): $575-77$.

22. Susan Edwards and Lynn Jones, "Assessing the Fitness of an Academic Library for Doctoral Research," Evidence Based Library and Information Practice 9, no. 2 (2014): 9-10.

23. Karen Antell, "The Citation Landscape of Scholarly Literature in LGBT Studies," College $\mathcal{E}$ Research Libraries 73, no. 6 (Nov. 2012): 584-91.

24. Melissa Adler, "Meeting the Needs of LGBTIQ Users and Their Librarians," in Serving LGBTIQ Library and Archives Users: Essays on Outreach, Service, Collections and Access, ed. Ellen Greenblatt (Jefferson, N.C.: McFarland, 2011): 188, 192.

25. Pascal Lupien, "GLBT/Sexual Diversity Studies Students and Academic Libraries: AStudy of User Perceptions and Satisfaction," Canadian Journal of Information and Library Science 31, no. 2 (2007): 138.

26. Suzy Taraba, "Collecting Gay and Lesbian Materials in an Academic Library," in Gay and Lesbian Library Service, eds. Cal Gough and Ellen Greenblatt (Jefferson, N.C.: McFarland, 1990): 28.

27. Clarke, "LGBTIQ Users and Collections in Academic Libraries," 85.

28. Adler, "Meeting the Needs of LGBTIQ Users and Their Librarians," 187-88.

29. Clarke, "LGBTIQ Users and Collections in Academic Libraries," 90-91.

30. Susan E. Searing, "How Libraries Cope with Interdisciplinarity: The Case of Women's Studies," Issues in Integrative Studies 10 (1992).

31. Taraba, "Collecting Gay and Lesbian Materials in an Academic Library," 30. 25.

32. Sylvia, "Citation Analysis as an Unobtrusive Method for Journal Collection Evaluation,"

33. Ellen Sexton, "Journal Use by Graduate Students as Indicated by Master's Theses Bibliographies at an Urban Commuter College, 1991-2004," Behavioral \& Social Sciences Librarian 24, no. 2 (2006): 97.

34. Ibid.

35. Gail Herrera, "Interlibrary Loan User Behaviors in an Academic Library," Journal of Interlibrary Loan, Document Delivery \& Information Supply 14, no. 2 (2003): 22.

36. Adler, "Meeting the Needs of LGBTIQ Users and Their Librarians," 190.

37. Clarke, "LGBTIQ Users and Collections in Academic Libraries," 91.

38. Ibid., 90-91. 